\title{
Limitations on Freedom of Expression in Practice of the European Court of Human Rights and the Notion of Disinformation
}

\section{Anđela Đukanović ${ }^{1}$ \\ Institute of International Politics and Economics, Belgrade, Serbia}

Submitted: 2021-08-03 • Accepted: 2021-10-05 • Published: 2021-10-19

\begin{abstract}
The phenomenon of disinformation spreading is a well-known phenomenon. The problem has intensified primarily due to advances in technology. In addition, there is an increased desire for additional information in circumstances of uncertainty and crisis. Some states even resorted to vague or too strict laws or derogations of rights in case of public emergency. While examining whether there is a need for interference with freedom of expression, it seems that the European Court of Human Rights does not give special relevance to the term of disinformation. Nevertheless, two key elements of disinformation can be distinguished. Disinformation is tied to the information's veracity and the intent of the information provider. When determining whether an interference with freedom of expression is justified, the European Court of Human Rights gives these elements some weight, along with comprehensive analysis of other relevant factors. Fear from spreading disinformation must not lead the authorities to simply adopt strict and/or vague laws with severe penalties, which might fail to meet the requirements of freedom of expression protection. However, the term of disinformation can have value in policymaking directed at raising the credibility of information in general.
\end{abstract}

Keywords: human rights, disinformation, fake news, the European Court of Human Rights, freedom of expression, pandemic.

\section{Graphical abstract}
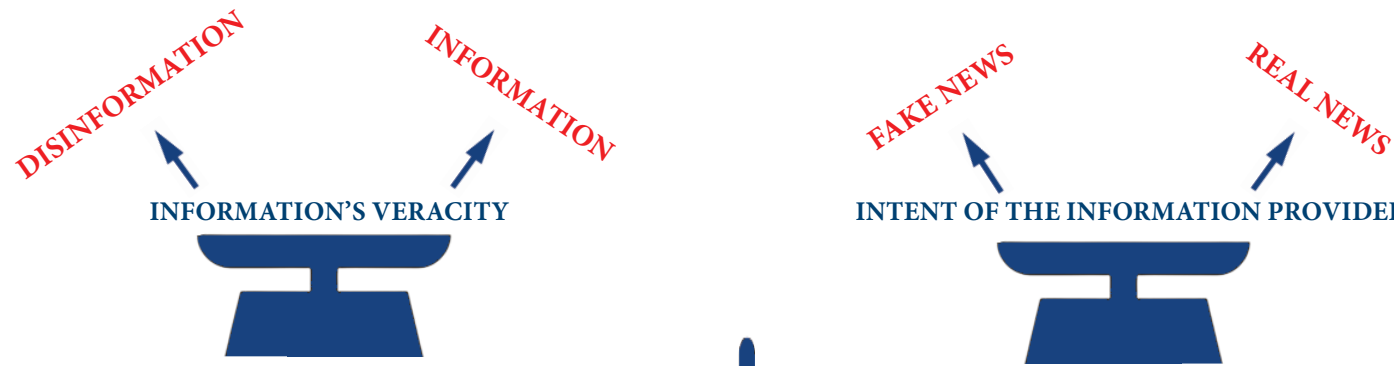

INTENT OF THE INFORMATION PROVIDER

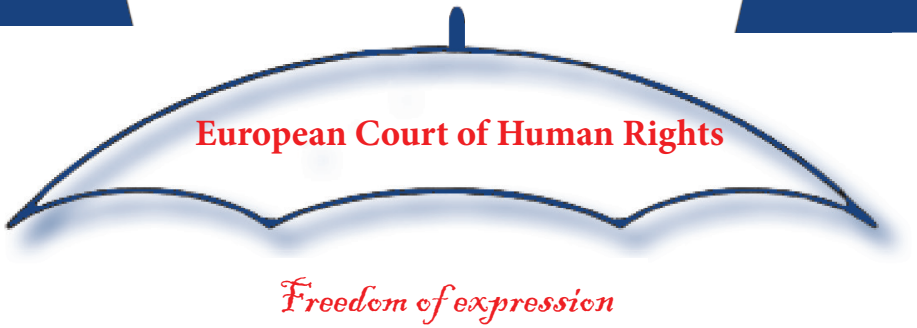

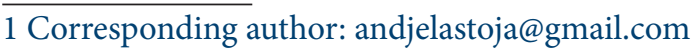

Citation: Đukanović, A. (2021). Limitations on freedom of expression in practice of the European Court of Human Rights and the notion of disinformation. NBP. Nauka, bezbednost, policija, 26(2), 31-42. https://doi.org/10.5937/ ISSN 2620-0406 nabepo26-33404 


\section{INTRODUCTION}

The problem of disinformation dissemination has become a particularly pressing issue. The phenomenon of disinformation dissemination is not new, but rather a well-known phenomenon. The problem intensified primarily as a result of technological development which enabled the possibility of rapid global spread, increased number of actors which provide information, difficult verification of the information accuracy and the authors' identity. In light of the pandemic and increased uncertainty about the new, unknown circumstances, there was an increased need for information, and different actors strove to meet this need in various ways. Therefore, there is a strong need to reconsider the disinformation phenomenon in light of international human rights protection, especially in relation to the possible limitations on freedom of expression, which are provided in international instruments that protect freedom of expression.

It may seem difficult to tackle disinformation and, at the same time, preserve freedom of expression. It seems that recipients are all victims of the proliferation of questionable content, which can harm their physical or psychological integrity. This type of intrusion could be sophisticated and hard to measure. Individuals with limited awareness of the medium are especially vulnerable and unable to make rational choices in favour of reliable information (Chang et al., 2021). The proliferation of questionable content can also endanger access to accurate information (Milanovic, 2020). On the other hand, an overly aggressive approach can lead to censorship and suppress critical ways of thinking, and therefore endanger freedom of expression.

Two key elements of the term disinformation can be distinguished: the truthfulness of the content and the intent of the information provider. The ECtHR recognized the importance of content truthfulness when balancing conflicting rights. However, the intent of the information provider did not attract significant attention as part of a test, despite having some significance in practice.

The ECtHR has established elaborate criteria when examining the justification of limitations on freedom of expression. In connection to this issue, an important question is whether the term disinformation has some special value in the practice of the ECtHR, or it is possibly the term better suited for the area of strengthening collective resilience to disinformation and policymaking in this sense. The problem of disinformation drew significant attention in Europe as well, with a particular emphasis on issues related to web expression.

\section{THE NOTION OF DISINFORMATION}

The term disinformation, as well as the very popular term of fake news, certainly does not have a clear meaning. These terms have different meanings for different authors, actors and laws, which also depend on the context used. They are most often used lightly and without clarification.

Disinformation could be defined as "dissemination of incomplete, inaccurate, or otherwise misleading information with the objective, goal, or aim of deliberately deceiving others about the truth" (Fetzer, 2004: 228). When it comes to the notion of fake news, it is 
possible to define fake news simply as "news articles that are intentionally and verifiably false, and could mislead readers" (Hunt \& Gentzkow, 2017: 213). It seems that fake news and disinformation mostly overlap, but the main difference is that the term of fake news is somewhat narrower, because it suggests some sort of novelty element, implying that the disinformation is presented as news. This might suggest that they should be "looking like, and coming across as traditional media" (Waldman, 2018: 849).

There is also a suggested category of "information disorder", which includes the useful distinction between three types of information: "mis-information is when false information is shared, but no harm is meant, dis-information is when false information is knowingly shared to cause harm, and mal-information is when genuine information is shared to cause harm" (Wardle \& Derakhshan, 2017: 5). It is significant to state that politicians often devalue undesirable content just by using the term fake news. Therefore, the term fake news bears more contempt as it is often used to initially discredit the information. The recently adopted definition of disinformation within the European Union appears to be the most elaborate. Disinformation is defined as: "verifiably false or misleading information that is created, presented and disseminated for economic gain or to intentionally deceive the public, and may cause public harm. Public harm comprises threats to democratic political and policymaking processes as well as public goods such as the protection of EU citizens' health, the environment or security. Disinformation does not include reporting errors, satire and parody, or clearly identified partisan news and commentary" (European Commission, 2018a).

From this definition, it seems that disinformation also covers mal-information, but only if it is verifiably misleading and with an intent directed at a certain aim. In the context of the protection of human rights, the last definition can serve as the basis for analysis. For some, hate speech and incitement to violence represent already illegal forms of speech, and therefore it is not necessary to include them in the definition of disinformation (European Commission, 2018c: 10). On the other hand, the above-mentioned European Commission definition includes illegal and unlawful statements (Hoboken et al., 2019: 25).

It should be noted that invoking the term fake news or disinformation always implies some sort of truth establishment, which may be apparent in a small number of cases. In most cases, the content is partially truthful, and in some cases, it is not yet clear what exactly the truthful information is. This issue has become more obvious in relation to the on-going pandemics and the matters that are not yet scientifically resolved. In addition, there is an element of intent to deceive recipients, which is certainly difficult to prove.

\section{TACKLING ONLINE DISINFORMATION IN EUROPE}

Within the European Union, some efforts have also recently been made to define coordinated action on disinformation issues (European Commission, 2018a). The Code of Practice on Disinformation was adopted in 2018, signed by online platforms such as Facebook, Google, Twitter and Mozilla, and later by Microsoft and TikTok (European Commission, 2018b). The Council of Europe has also made some efforts to address media anomalies trough different acts. 
There has also been an increase in the authorities' individual efforts to combat undesirable content in the context of national security or public order in Europe, especially as a response to pandemic. This battle sometimes includes the right to determine which information is suitable for printing or broadcasting just by invoking the notion of fight against false news (Council of Europe, 2020).

Legislative amendments that have been adopted in the Russian Federation recently, mostly justified on the grounds of countering terrorism and promoting public safety, may fail to limit the interference strictly to what is necessary in a democratic society (Moyakine \& Tabachnik, 2021). In Hungary, at the beginning of pandemics, the fear of distribution of disinformation concerning the coronavirus led the authorities to amend the Hungarian Criminal Code, introducing in Article 337 (2) jail terms of up to five years for criminal offence of scaremongering in state of danger (Criminal Code, Republic of Hungary, 2012). The issue of tackling online disinformation was also an evident problem for the states before the outbreak of the pandemic. Germany's Network Enforcement Act, adopted in 2017, imposes severe fines on social media and platform providers if they fail to swiftly remove content that is unlawful under the relevant Criminal Code provisions (Network Enforcement Act, 2017).

The term of fake news for example has a long history in Serbian criminal law, which dates back to the former SFRY, although it has gained significant global popularity relatively recently. If disclosing or spreading fake news or statements causes panic, or serious disruption of public law and order, or enforcement of decisions and measures of government authorities or organizations exercising public authority, the perpetrator can be punished by up to three years of imprisonment under Article 343 of the Serbian Criminal Code (Krivični zakonik, 2005). The official English translation inaccurately uses different terms than the original text: "untrue information", instead of "fake news" or possibly "false news" (Criminal Code, Republic of Serbia, 2019). It seems that the used term lacks the intent element, therefore bringing it closer to the term false news, since if there is no intent, there is no criminal offence. The intent is necessary in relation to the untruthfulness of news and statements, and in relation to the stated consequences. This is certainly difficult to prove, and this criminal offence must be applied very cautiously, since it involves several ambiguous terms (Stojanović, 2020).

\section{RESTRICTIONS UNDER ARTICLE 10 (2) OF THE ECHR}

Freedom of expression is not absolute, and the exercising this freedom entails appropriate duties and responsibilities. According to Article 10 (2) of the European Convention for the Protection of Human Rights and Fundamental Freedoms (hereinafter, ECHR), freedom of expression may be: "Subject to such formalities, conditions, restrictions or penalties as are prescribed by law and are necessary in a democratic society, in the interests of national security, territorial integrity or public safety, for the prevention of disorder or crime, for the protection of health or morals, for the protection of the reputation or rights of others, for preventing the disclosure of information received in confidence, or for maintaining the authority and impartiality of the judiciary". 
Article 19 (3) of the Covenant on Civil and Political Rights also provides an exception to the freedom to seek, receive and impart information and ideas of all kinds. Article 11 of the European Charter on Fundamental Rights is devoted to freedom of expression and information, and corresponds to Article 10 of the Convention.

In considering the justification of the restriction on freedom of expression, the ECtHR has developed a basic test of necessity, based on the wording of Article 10 (2) of the ECHR, which must be met cumulatively. The national authorities must have valid reasons for their decision to limit freedom of expression. Restriction on freedom of expression, which is prescribed by law, must be aimed at achieving one of the legitimate goals stated in the wording of Article 10 (2) of the ECHR, and it must be necessary in a democratic society. When deciding on the justification of a restriction on freedom of expression, the ECtHR examines whether it was proportionate to the aim pursued (Hertel v. Switzerland, 1998: 46). Concerning the requirement of "necessary in a democratic society", the ECtHR acknowledged that the term necessary implies the existence of a pressing social need (Perinçek v. Switzerland, 2015: 196). The scope of Article 10 of the ECHR also includes the freedom to disseminate opinions.

In the event of a human rights conflict, the ECtHR balances different opposing values, i.e. human rights. The balancing must be done in accordance with the provisions of the ECHR and the criteria of the Court's case law (Perinçek v. Switzerland, 2015: 198). The UN Human Rights Committee also relies on the proportionality test (UN Human Rights Committee, 2011: 34).

The ECtHR laid down in its case law the relevant criteria when balancing: contribution to a debate of general interest, how well known the person concerned and the subject of the report are, prior conduct of the person concerned, the method of obtaining the information and its veracity, content, form and the consequences of the publication, and the severity of the sanction imposed (Axel Springer AG v. Germany, 2012).

The proportionality test has been criticized and involves determining whether a particular measure affects human rights and, if so, whether such interference with human rights is justified. The measure must be aimed at achieving a legitimate goal, adequate to that goal, necessary (in the sense that it has the least impact on the exercise of the freedom in question), and have proportional effects (Urbina, 2014: 167). One criticism is that the proportionality test involves balancing freedom of expression, on the one hand and collective interests, such as health, national security or morality, on the other, thus placing them at the same normative level. As such, it promotes the interests of the majority (Gunatilleke, 2021). The ECtHR does not give special relevance to the term of disinformation. When balancing the conflicting rights, the ECtHR considers the truthfulness of the content, which is one of the main elements of the suggested definition of disinformation. Another element is the intent to deliberately deceive the public, but it seems that this element is not represented in practice as a key element when examining the validity of limitations on freedom of expression. The introduction of the term disinformation or fake news in practice could imply the introduction of "intention-based tests", although the human rights courts have expressed reservations about focusing on this element, most likely due to difficulties in proving it (Sardo, 2020: 458). However, the ECtHR should examine whether the domestic authorities had reasonably investigated the existence of intent and considered the findings when deciding. This does not mean that the ECtHR does not give any significance to the 
notion of intent. For example, in one interesting case concerned the posting of a link to defamatory content, the ECtHR found a violation of Article 10 of the Convention. The ECtHR questioned whether the journalist endorsed the impugned content, whether the journalist repeated it (without endorsing it), or simply included a hyperlink to it (without endorsing or repeating it). It also looked into whether the journalist knew, or could have reasonably known, that the impugned content was defamatory or otherwise unlawful, and whether he acted in good faith while adhering to journalistic ethics and performing due diligence (Magyar Jeti Zrt v. Hungary, 2018: 77). In another case, the ECtHR concluded that the domestic courts had failed to prove that the complainant was intentionally trying to deceive voters (Salov v. Ukraine, 2005: 113). Of course, the intent of the information provider is not relevant in every situation involving restrictions on freedom of expression. The content could also be accurate. For example, this is the case with pornographic content, the protection of minors, and other cases related to the protection of the private life of the person.

In general, case law criteria on balancing rights are primarily aimed at balancing with the protection of an individual's private life, most often the right to reputation element, rather than, the impact of disclosure on an individual's physical or mental health in broader sense. Therefore, freedom of expression can also be examined if Article 8 of the ECHR is invoked. The ECtHR then usually examines if the right to reputation is endangered by questionable content, and relies on the principles formulated in the case law on Article 10 of the ECHR. If, for example, the physical or mental health of an individual is significantly endangered by questionable content, states do have the positive obligation to take adequate measures in accordance with Article 8 of the ECHR (or sometimes even Article 3 or 2 of the ECHR). An adequate legal framework is necessary to protect individuals, which does not always imply the necessity of criminal-law provision (Söderman v. Sweden, 2013). However, there is still no case in the ECtHR's practice where questionable information endangered the mental or physical health of an individual to a significant extent. The ECtHR would likely find a violation of Article 8 of the ECHR if a direct link between content and significant consequences for physical or mental health exists, and a pressing social need to limit such expression, directed at one of the legitimate aims, if the state failed to limit such expression. This issue has become important in relation to the consequences of information related to the COVID-19 pandemics. For example, there is the possibility of spreading information about the effectiveness of medicine against disease or vaccine efficiency or inefficiency, without any scientific basis. Of course, the situation becomes more complicated when it is not clear what the scientific truth is, or in the case of a misinterpretation of scientific findings.

When it comes to the previously mentioned relevant criteria for balancing rights, the question of contribution to the public debate will depend on the circumstances of the specific case. However, in the area of political speech, the ECtHR, in practice, was not in favour of restricting it. The public interest is also present, for example, in matters concerning the functioning of the judicial system, public health and environmental protection. According to the ECtHR, the public interest usually relates to matters that affect the public to such an extent that it may have a legitimate interest in them, and which concern the public to a significant extent, particularly if they affect the well-being of citizens or community life (Satakunnan Markkinapörssi Oy and satamedia Oy v. Finland, 2017: 171). On the other 
hand, the margin of appreciation of States is broader in the commercial sphere, as well as in relation to protection of morals (Handyside v. The United Kingdom, 1976: 57).

With regard to the to the question of how well known the person to whom the disputed content relates was, the ECtHR was inclined to distinguish between private individuals and persons acting in a public context. In that sense, private persons have the right to a higher level of protection than public persons in whose private lives the public will be interested in special circumstances, provided that this will not be the case if the disputed content serves the purpose of satisfying the public curiosity (Axel Springer AG v. Germany, 2012: 91).

In light of the phenomenon of disinformation, it is of particular importance when balancing rights how information is obtained and its truthfulness. The ECtHR stated that Article 10 of the ECtHR protects the right of journalists to freedom of expression in matters of public interest, provided that they act conscientiously, on an accurate factual basis, and provide "reliable and precise" information in accordance with journalistic ethics (Couderc and Hachette Filipacchi Associés v. France, 2015: 131). The ECtHR found a violation of Article 10 of the ECtHR in the case where the applicant company was penalized for broadcasting information obtained by someone else illegally. In this case, there was no evidence that the journalists acted recklessly, and the domestic courts did not determine information's veracity (Radio Twist a.s. v. Slovakia, 2006).

As for the content, form and consequences of the disputed publication, the ECtHR stated that it is not up to it or the domestic courts to replace their own views with those of information sources, implying that there must be journalistic freedom in this regard. However, they must consider the possible impact of the information before publishing them. Reduced and selective content, which is suitable to mislead the reader, is likely to significantly diminish the importance of the contribution of such content to a debate of the public interest (Couderc and Hachette Filipacchi Associés v. France, 2015). From this, it seems that mal-information, in terms of selecting accurate information presented in a way that seems likely to draw erroneous conclusions, is taken into account, but as a factor that diminishes the relevance of the content to the public interest. To some extent, freedom of the press entails the use of exaggeration or provocation (Radio Twist a.s. v. Slovakia, 2006: 51). Satire is also a legitimate form of expression, which has the properties of exaggerating and distorting reality, with the aim of provoking, and any interference with the right to this type of expression must be examined with due care (Vereinigung Bildender Künstler $v$. Austria, 2007: 33). The degree of dissemination of content is also relevant and the Court's attitude towards the Internet. Namely, the ECtHR is of the opinion that there is a higher risk of human rights violations via the Internet than through other media, such as the press, since the information can be disseminated very quickly, worldwide, and can remain available online for a long period of time (Delfi AS v. Estonia, 2018).

With regard to the severity and nature of the sanction as a relevant criterion, the ECtHR is of the opinion that imprisonment in the case of crimes committed through the press or other media is compatible with journalists' freedom of expression only in exceptional circumstances, especially when other fundamental rights are seriously violated, such as in the case of hate speech or incitement to violence (Ruokanen and Others v. Finland, 2010: 50). The adequacy of the sanction imposed depends on the circumstances of the specific case. Therefore, it must be assessed whether the desired goal could be achieved through a less intrusive measure. 
As a particularly topical issue, health protection can be singled out as a reason for restricting freedom of expression. The ECtHR is of the opinion that this area enjoys a higher level of protection of freedom of expression, since it is not about statements of a purely commercial nature, but a topic of public interest (Hertel v. Switzerland, 1998: 47). Thus, in the Court's view, research into the impact of microwave ovens on human health belongs to this sphere. The ECtHR underlined the manner in which the text containing the research results was formulated in this case, i.e. the use of less categorical formulations, such as that the results "may" correspond to the onset of cancer (Hertel v. Switzerland, 1998: 48), which is why the ECtHR found a violation of Article 10 of the ECtHR.

\section{PUBLIC EMERGENCY LIMITATIONS}

Limitations on freedom of expression in the event of an emergency were a significant issue in light of pandemics. According to Article 15 of the ECHR, there is a possibility of taking measures derogating from obligations under the Convention at the time of war or other public emergency. This is, however, possible only "to the extent strictly required by the exigencies of the situation", and with the obligation of informing the Secretary-General of the Council of Europe about such measures. Ten State Parties introduced derogations related to the COVID-19 pandemic at the beginning of the outbreak. Romania has introduced measures aimed directly at fake news (Council of Europe Treaty Office, 2020). The requirement of a "public emergency threatening the life of the nation" is fulfilled in the case of the COVID-19 pandemic. However, when it comes to the question of derogation necessity in the case of Article 10 of the ECHR, the limitations contained in Article 10 (2) are clearly sufficient in dealing with possible threats from unlimited freedom of expression in the case of pandemics. For example, this is also the case in relation to public gatherings when exercising freedom of speech.

\section{ABUSE OF FREEDOM OF EXPRESSION}

The ECHR contains a general provision focused on the prohibition of abuse of rights in Article 17, which aims at preventing states, groups or persons, from using the provisions of the ECHR to destroy safeguarded rights and freedoms, or to limit them to a greater extent. The prohibition of abuse of rights (Article 17) played a role in the ECtHR's practice, mostly in cases related to freedom of expression. The inclusion of Article 17 in the ECHR is justified by the possibility of relying on the rights enshrined in the ECHR, in order to conduct activities intended to destroy those very same rights (Perinçek v. Switzerland, 2015: 113). Article 17 of the ECHR is tied to possible abuse of some other rights from the ECHR, and therefore cannot be invoked independently. In practice, the ECtHR uses Article 17 directly, or indirectly, as a form of aid in its interpretation. The ECtHR has also made a new distinction in recent practice. It is applicable exceptionally, and in extreme cases, also taking into account that the abuse of rights is not immediately clear, and actually overlaps with the question of whether the interference with the applicant's right to freedom of expression was "necessary in a democratic society" (Perinçek v. Switzerland, 2015: 114-115). 
In the cases where Article 17 of the ECHR was directly applied, the ECtHR however did not assess claims extensively under Article 10 (2) of the ECHR. The most recent example of the direct application of Article 17 of the ECHR concerned the articles which in the ECtHR's opinion openly called for an armed civil conflict (Romanov v. Ukraine, 2020:163). The messages in question constituted a threat to public order and democracy, and therefore were excluded from the protection afforded by Article 10, in accordance with Article 17 of the ECHR. However, in case of the indirect application, Article 17 of the ECHR represents just an aid to the ECtHR in interpretation, giving additional weight to the necessity of the limitation on freedom of expression. The ECtHR must consider the justification of the limitations on freedom of expression, and apply all the principles deriving from the case law under Article 10 of the ECHR. This was, for example, the situation in a case involving a claim that a criminal conviction of incitement to hatred had breached right to freedom of expression. The ECtHR also considered the nature and severity of the imposed sanction, finding it to be very lenient (Williamson v. Germany, 2019). There are concerns that disinformation in the strict sense could be considered under the scope of Article 17 of the ECHR, deepening uncertainty in the already challenging area (Shattock, 2021). It is unlikely that the ECtHR will do so, but the exact scope of Article 17 is certainly puzzling. Acts amounting to hatred, violence, xenophobia, racial discrimination, terrorism, war crimes, and revision of historical facts are examples of acts that could trigger the abuse clause application in the ECtHR's practice. The direct application of Article 17, without an analysis under Article 10 (2), is not justified because the latter is sufficient in dealing with the worst types of speech while also adequately protecting from the excessive restriction on rights (Cannie \& Voorhoof, 2011).

\section{CONCLUSION}

The ECtHR's practice is slowly adapting to the new circumstances and the fact that journalism is a function shared by a variety of actors. The notion of disinformation or fake news does not play any special role in the process of evaluation of whether interference with the exercise of freedom of expression is justified. If the ECtHR simply evaluated whether some content could represent fake news or disinformation, without assessing all the relevant criteria, it would be harmful. Even if applied as an additional test, it would bear some sort of pre-conclusion on the interference justification, since the terms of the fake news or disinformation represent independent qualifications, used on daily basis to discredit content. However, one key element of disinformation has found its place in the balancing rights test: information veracity. As for the other element, that the content is presented and disseminated to deceive the public intentionally, it does not represent a part of any well-established test. The ECtHR might benefit from questioning the intent of information provider on a more regular basis if the domestic courts have failed to address this issue in appropriate cases.

When it comes to the issue of content presented and disseminated for economic gain, which is also relevant in the EU disinformation definition, the ECtHR reiterated that the margin of appreciation of States is broader in the commercial sphere. The practice of the ECtHR also confirms that satire and parody are a legitimate form of expression. In addi- 
tion, the ECtHR takes into account the selection of accurate information presented in a way that seems likely to draw erroneous conclusions (mal-information), but as a factor that diminishes the relevance of the content to the public interest.

The prohibition of abuse of rights from Article 17 of the ECHR should only be resorted to exceptionally, accompanied with the analysis under Article 10 (2) of the ECHR, which is quite adequate for dealing with all types of expression and also for the protection of the information providers. This is especially evident in relation to the criteria of severity and the nature of the imposed sanction, that is, whether it was appropriate. Additional limitations in times of public emergency from Article 15 of the ECHR also seem unnecessary in relation to the pandemics.

However, the term of disinformation can have value in policymaking. Tackling disinformation can involve improvement in transparency regarding the origin of information, the promotion of information diversity, raising media literacy and the credibility of information in general. These issues have great value in the environment of information proliferation when a person's right to integrity may be jeopardized by various types of information, particularly during the times of crisis. Fear from spreading disinformation must not lead the authorities to simply adopt and/or apply strict and/or vague laws with severe penalties, which might fail to meet the requirements of freedom of expression protection.

\section{ACKNOWLEDGMENT}

This paper is the result of the Project 47011 "Crime in Serbia: Phenomenology, Risks and Possibilities of Social Intervention", funded by the Ministry of Education, Science and Technological Development.

\section{REFERENCES}

Axel Springer AG v. Germany (2012). Application no. 39954/08, Grand Chamber judgment of 7 February.

Cannie, H., \& Voorhoof, D. (2011). The abuse clause and freedom of expression in the European Human Rights Convention: An added value for democracy and human rights protection? Netherlands Quarterly of Human Rights, 29(1), 54-83. https://doi.org/10.1177 \%2F016934411102900105

Chang, L. Y. C., Mukherjee, S., \& Coppel, N. (2021). We are all victims: Questionable content and collective victimisation in the digital age. Asian Journal of Criminology, 16, 37-50. https://doi.org/10.1007/s11417-020-09331-2

Couderc and Hachette Filipacchi Associés v. France (2015). Application no. 40454/07, Grand Chamber judgment of 10 November.

Council of Europe. (2020). Hands off press freedom: Attacks on media in Europe must not become a new normal. https://rm.coe.int/annual-report-final-en/16809f03a9 
Council of Europe Treaty Office. (2020). Notification - JJ9014C Tr./005-226,18 March 2020, Declaration related to the Convention for the Protection of Human Rights and Fundamental Freedoms (ETS No. 5). https://rm.coe.int/16809cee30

Criminal Code, Republic of Hungary, as amended by the Act C of 2012 on the Criminal Code. Magyar Közlöny, 2012-07-13, vol. 92, pp. 1-122.

Criminal Code, Republic of Serbia (2019). Službeni glasnik Republike Srbije, 35/19. https:// www.mpravde.gov.rs/files/Criminal\%20\%20\%20Code_2019.pdf

Delfi AS v. Estonia (2018). Application no. 64569/09, Grand Chamber judgment of 28 June.

European Commission (2018a). Tackling online disinformation: A European approach. COM (2018) 236 final. https://eur-lex.europa.eu/legal-content/EN/ TXT/?ri=ELEX\%3A52018DC0236

European Commission (2018b). EU Code of practice on disinformation. https:// digitalstrategy.ec.europa.eu/en/policies/code-practice-disinformation

European Commission (2018c). A multi-dimensional approach to disinformation: Report of the independent High level Group on fake news and online disinformation. Publications Office of the European Union. https://op.europa.eu/en/publication-detail/-/ publication/6ef4df8b-4cea-11e8-be1d-01aa75ed71a1/language-en

Gunatilleke, G. (2021). Justifying limitations on the freedom of expression. Human Rights Review, 22(1), 91-108. https://doi.org/10.1007/s12142-020-00608-8

Handyside v. The United Kingdom (1976). Application no. 5493/72, judgment of 7 December. Hertel v. Switzerland (1998). Application No. 59/1997/843/1049, judgment of 25 August.

Hoboken, J. Van, Appelman, N., Ó Fathaigh, R., Leerssen, P., McGonagle, T., Eijk, N. Van, \& Helberger, N. (2019). The legal framework on the dissemination of disinformation through Internet services and the regulation of political advertising: Final report. Institute for Information Law. https://www.ivir.nl/publicaties/download/Report_Disinformation_ Dec2019-1.pdf

Hunt, A., \& Gentzkow, M. (2016). Social media and fake news in the 2016 election. Journal of Economic Perspectives, 31(2), 211-236. http://dx.doi.org/10.1257/jep.31.2.211

James, H. F. (2004). Information: Does it have to be true? Minds and Machines, 14(2), 223-229. https://doi.org/10.1023/B:MIND.0000021682.61365.56

Krivični zakonik (KZ), Republika Srbija (2005). Službeni glasnik Republike Srbije, 85/05, 88/05 - ispravka, 107/05 - ispravka, 72/09, 111/09, 121/12, 104/13, 108/14, \& 94/16.

Magyar Jeti Zrt v. Hungary (2018). Application no. 11257/16, judgment of 4 December.

Milanovic, M. (April 2020). Viral misinformation and the freedom of expression: Part II. EJIL: Talk! https://www.ejiltalk.org/viral-misinformation-and-the-freedom-ofexpression-part-ii/

Moyakine, E., \& Tabachnik, A. (2021). Struggling to strike the right balance between interests at stake: The 'Yarovaya', 'Fake news' and 'Disrespect' laws as examples of ill-con-

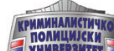


ceived legislation in the age of modern technology. Computer Law \& Security Review, 40, 1-13. https://doi.org/10.1016/j.clsr.2020.105512

Network Enforcement Act (Netzdurchsetzunggesetz, NetzDG). (2017). Federal Law Gazette I, p. 3352 ff. https://germanlawarchive.iuscomp.org/?p=1245

Perinçek v. Switzerland (2015). Application no. 27510/08, Grand Chamber judgment of 15 October.

Radio Twist a.s. v. Slovakia (2006). Application no. 62202/00, judgment of 19 December.

Romanov v. Ukraine (2020). Application no. 63782/11, judgment of 16 July.

Ruokanen and Others v. Finland (2010). Application no. 45130/06, judgment of 6 April.

Salov v. Ukraine (2005). Application no. 65518/01, judgement of 6 September.

Sardo, A. (2020). Categories, balancing, and fake news: The jurisprudence of the European Court of Human Rights. Canadian Journal of Law \& Jurisprudence, 33(2), 435-460. http:// dx.doi.org/10.1017/cjlj.2020.5

Satakunnan Markkinapörssi Oy and satamedia Oy v. Finland (2017). Application no. 931/13, Grand Chamber judgment of 27 June.

Shattock, E. (2021). Should the ECtHR invoke Article 17 for disinformation cases? Blog of the European Journal of International Law. https://www.ejiltalk.org/should-the-ecthrinvoke-article-17-for-disinformation-cases/

Söderman v. Sweden (2013). Application no. 5786/08, Grand Chamber judgment of 12 November 2013.

Stojanović, Z. (2021). Komentar Krivičnog zakonika. Službeni glasnik.

UN Human Rights Committee, General comment no. 34 Article 19: Freedoms of opinion and expression, 102nd session, Geneva, 11-29 July 2011, CCPR/C/GC/34. https://www2. ohchr.org/english/bodies/hrc/docs/gc34.pdf

Urbina, F. J. (2014). Is it really that easy? A critique of proportionality and 'balancing as reasoning. Canadian Journal of Law \& Jurisprudence, 27(1), 167-192. https://doi. org/10.1017/S0841820900006275

Vereinigung Bildender Künstler v. Austria (2007). Application No. 68354/01, judgment of 25 January.

Waldman, A. E. (2018). The marketplace of fake news. Journal of Constitutional Law, 20(4), 849-870. https://scholarship.law.upenn.edu/jcl/vol20/iss4/3

Wardle, C., \& Derakhshan, H. (2017). Information disorder toward an interdisciplinary framework for research and policymaking. Council of Europe. https://edoc.coe.int/en/ media/7495-information-disorder-toward-an-interdisciplinary-framework-for-researchand-policy-making.html

Williamson v. Germany (2019). Application no. 64496/17, admissibility decision of 8 January. 